\title{
O PAPEL DO ENFERMEIRO DE SAÚDE PUBLICA: PROJEÇÕES NO ENSINO'
}

Bertha Cruz Enders²

RESUMO: Analisa-se o papel do enfermeiro em saúde pública no contexto do ensino, como ponto de partida para uma avaliaçăo da prática. Objetivou-se 1) Identificar o papel do enfermeiro em saúde pública projetado nos conteúdos programáticos das disciplinas de saúde pública do Curso de Enfermagem na Universidade Federal do Rio Grande do Norte desde sua implantação em 1974 até 1990 e, 2) Avaliar as concepções projetadas no ensino frente a realidade das práticas dos egressos. Conceptualizaçőes da teoria de papeis nortearam o entendimento do termo "papel" e do processo de internalização do conceito. Utilizou-se uma abordagem qualitativa com triangulação na coleta de dados. Dados foram obtidos em duas fontes: nos conteúdos programáticos do Curso e nas opiniőes dos enfermeiros egressos do Curso. Técnicas de análise documental foram aplicadas a 70 programas de disciplinas de Saúde Pública e uma amostra aleatória estratificada de 60 enfermeiros foi entrevistada utilizando um questionário específico. Os dados foram analisados à luz da teoria de papeis para a identificação do conceito. Em seguida, se analisou o conceito com base nas políticas de saúde vigentes da época em estudo. Os resultados demonstram que o papel do enfermeiro em saúde pública projetado nos conteúdos focaliza funções múltiplas, assistenciais educativas e administrativas dentro de uma visão preventiva. O objetivo da enfermagem em saúde pública tem sido a prevenção, dentro de uma prática de assisténcia primária e mais recentemente, dentro de uma perspectiva de mudança e de transformaçăo das questões sociais e das políticas de saúde. Focaliza o enfermeiro planejador, competente nas técnicas epidemiológicas. A percepçăo dos egressos é também preventiva e focaliza o papel educador e conscientizador do enfermeiro, embora pouco avanço se observa com relação às questões sociais da população. Existe uma incompatibilidade entre os conceitos expressos no curso e os exigidos na prática profissional, refletindo insatisfaçăo dos egressos com a formação recebida no Curso que ressaltam insegurança técnica na prática. Conclui-se que o conceito da prática de enfermagem em saúde pública tem atendido as demandas das políticas de saúde vigentes, porém năo as demandas da prática do enfermeiro. Tal divergência entre o ensino e a prática de enfermagem em saúde pública aponta a necessidade de uma revisão curricular no que tange o objeto de trabalho da enfermagem em saúde pública.

UNITERMOS: Enfermagem em Saúde Pública e Educaçăo em Enfermagem - Prática de Saúde Pública

\section{INTRODUÇÃO}

As mudanças no setor saúde advindas do Sistema Único de Saúde (SUS), levantam a necessidade de uma definição dos rumos que a enfermagem brasileira deverá tomar nesse pro- cesso de reforma. Nessa perspectiva, a categoria de enfermagem dá inicio, no final da década de 80 , ao processo de reformulação do currículo mínimo em enfermagem visando uma aproximação entre o ensino e a prática e uma condicéncia com os principios do SUS.12, 24

1 Projeto financiado pelo CNPq, Processo No 403019-90.7

2 PhD em Enfermagem, Professora Adjunta, Departamento de Enfermagem/UFRN. 
Nessa definiçăo de novos modelos de assisténcia e de enfermagem, torna-se necessário avaliar as conceptualizações do papel do enfermeiro que se processam no ensino, a adequaçăo desses conceitos à prática e os fatores que os determinam, para, a partir daí, efetuar novas visões e açőes de enfermagem que possam atender as necessidades de saúde da populaçăo. $O$ objeto de estudo neste trabalho, portanto, é o papel do enfermeiro em saúde pública projetado em um Curso de Graduação em Enfermagem, como ponto de partida para uma avaliação da prática e do ensino na área de Saúde Pública, visando uma renovação desses conceitos.

\subsection{Problemática e Objetivos}

As funçס̃es do enfermeiro em saúde pública têm sido explicitadas oficialmente e teoricamente na literatura da enfermagem brasileira. Em 1975, por exemplo, NOGUEIRA 21 define "o que", "o como"e o "para que" das tarefas do enfermeiro e subsidia o registro da ocupaçăo "Enfermeira em Saúde Pública" na Classificação Brasileira de Ocupações no Ministério do Trabalho e Previdéncia Social (MTPS). Na época, o conteúdo global da prática visava o "planejamento, execução e avaliação dos programas de saúde" através de ações técnico-administrativas, da prestação de cuidados, de programas educativos e de pesquisa, orientados para a "promoção, proteção e recuperação da saúde de uma coletividade" 21 (p.119). Já em 1977, o Ministério de Saúde, define os padrões mínimos de assistência de enfermagem à comunidade nas diversas atividades no sentido "de orientar as ações de enfermagem nos programas de extensão dos serviços de saúde nas áreas rurais, de proteção materno-infantil, de nutrição e de vigilância epidemiológica" 8 (p.10). Vários proposições teóricas sobre as funções do enfermeiro em saúde pública são apresentadas na literatura de enfermagem. 1,3,11,13

Tais definições, porém, enfatizam o ideal da função do enfermeiro frente aos programas de saúde do Ministério de Saúde vigentes. Carecem de uma constatação do real papel desem- penhado pelo enfermeiro na prática, ou seja, de uma abordagem indutiva onde a teoria dessa função seria elaborada com base nas realidades vivenciadas pelos enfermeiros nas suas práticas em conjunto com as politicas de assistência à saúde.

Quanto ao ensino, estudos recentes em saúde pública, têm constatado a ineficiência do ensino no preparo do profissional para a prática. ${ }^{9}$ O distanciamento do profissional de enfermagem das políticas de saúde, ensino das ações centradas nos aspectos curativos e o descompromisso social no cotidiano do enfermeiro em geral, são aspectos questionados fortemente, especialmente frente aos princípios do SUS que exige uma prática baseada nas necessidades de saúde da população alvo. ${ }^{2,20}$

O problema investigado neste estudo é a relação entre o ensino curricular de enfermagem e a prática, numa conceituação específica, a do papel do enfermeiro de saúde pública. Os objetivos do estudo foram: 1) identificar as características e os determinantes do papel do enfermeiro em saúde pública enfocado no ensino; 2) Identificar as concepções dos egressos sobre o papel do enfermeiro em saúde pública adquiridas durante a sua formação e sobre sua correspondéncia na prática; 3) Analisar a adequação do conceito projetado no ensino, frente aquele internalizado pelos enfermeiros egressos e a realidade de trabalho.

\subsection{Referencial Teórico e Questões de Pes- quisa}

O trabalho parte do pressuposto de que a prática de enfermagem, como prática social e histórica, abriga determinantes contextuais relacionados ao processo de formação, que por sua vez, socializa o profissional para a prática, direcionando os valores, as atitudes e as ações que nortearão seu papel. Reconhece-se ainda, que as expectativas, as situações do ambiente de trabalho e as motivações individuais do profissional contribuem para o desenvolvimento do papel a ser assumido na prática. Dessa forma, o papel do enfermeiro é visto como produto da interrelação. entre o ensino, o contexto sócio- 
político, a situação de trabalho e as motivações pessoais.

Para conceptualizar essa relação conteúdoprática no currículo, utilizou-se o esquema de planejamento do ensino de BOTOMÉ que propõe o currículo derecionado para a realidade social do contexto. ${ }^{7}$ Segundo o autor, a base do currículo deverá ser a realidade com a qual o aluno tomará contato, ou seja, o currículo deverá partir da situação que ele vivenciará. As açőes relacionadas ao conteúdo devem ser direcionadas para o preparo do profissional enfermeiro capaz de lidar com as situações da prática.

A teoria de papeis norteia a concepção do termo "papel". Segundo LINTON Apud HINSHAW, ${ }^{17}$ qualquer "papel" (ou 'role') é formado por três componentes: valores, atitudes e comportamentos. Valores são idéias mantidas em comun por membros de uma estrutura social, (neste caso, a categoria de enfermagem), que guiam a identificação e a priorizaçăo das metas e objetivos dos individuos.

Atitude é entendido como a tendéncia ou a prontidão para responder a objetos ou eventos da profissão de forma favorável ou desfavorável, podendo ser expressada através de opiniőes. Na teoria de papeis, atitude predispőe o indivíduo a ter certas expectativas de comportamento acerca do indivíduo que exerce algum papel. Assim, as atitudes adquiridas acerca da sua profissão, predispõem o profissional enfermeiro a certas expectativas sobre o seu papel. Posteriormente, essas atitudes servem de guia para a avaliação de seu próprio desempenho. Tais atitudes, se formam através da socializaçăo de maneira informal nas experiências da vida, e através dos processos formais de ensino. ${ }^{17}$

Os comportamentos de um papel profissional referem-se às ações e às habilidades necessárias para desenvolver o trabalho especifico esperado. ${ }^{17} \mathrm{Na}$ enfermagem de saúde pública, os comportamentos săo diversos e requerem habilidades epidemiológicas, técnico-assistenciais, educativas e de comunicaçăo.

A formaçăo profissional foi considerada como um processo de socializaçăo, onde o propósito das instituiçőes formadores de profissionais é inculcar, nos seus aspirantes, as normas, os valores e os comportamentos necessários para, não só a sobrevivéncia da profissão, mas também, para a análise crítica da mesma e sua subsequente transformação. Conforme as proposições de ROSOW Apud HINSHAW, ${ }^{17}$ esse processo de socialização acontece através da internalização dos valores e das atitudes especificos à profissão e através da aprendizagem dos conhecimentos e das ações e habilidades necessárias para efetuar os comportamentos daquele papel profissional. Ainda, segundo LUM, ${ }^{19}$ a socialização de uma profissão requer, não apenas uma educação formal, mas também, um sistema informal para a internalização da ética que guia a prática do papel profissional.

Foi a tese deste trabalho, portanto, que o conjunto de valores, atitudes e comportamentos técnico-científicos, profissionais e éticos do enfermeiro em saúde pública, é determinado pelas expectativas sociais e de saúde vigentes e pela categoria. Tais elementos săo transmitidos no ensino da Enfermagem, através dos currículos, podendo ser identificados nos conteúdos e nas representações dos enfermeiros formados que os internalizam.

As questões de pesquisa foram: Qual o papel do enfermeiro de saúde pública projetado no ensino? Qual a percepçăo do papel do enfermeiro em saúde pública adquirida pelos graduados? Até que ponto o papel do enfermeiro em saúde pública projetado no ensino se compatibiliza com as expectativas dos enfermeiros na prática? Até que ponto os conceitos e enfermagem em saúde pública utilizados no ensino se relacionam com a situaçăo contextual, socio-económica, política e de trabalho, nos serviços de saúde?

\section{MATERIAIS E MÉTODOS}

O estudo foi realizado de janeiro 1991 a dezembro 1993 na Universidade Federal do Rio Grande do Norte. Teve como objeto os conteúdos programáticos na área de enfermagem em saúde pública no Curso de Obstetrícia e Enfermagem desde seu início em 1974 até 1990 e a prática dos egressos. Uma abordagem de aná- 
lise qualitativa foi utilizada, com triangulaçăo metodológica consistente na coleta de informações em duas fontes: nos conteúdos programáticos do Curso de Enfermagem e nas conceptualizações dos enfermeiros egressos. Realizou-se uma análise dos programas das disciplinas de enfermagem em saúde pública e um "survey"dos enfermeiros egressos do Curso.

\subsection{Análise Documental}

Setenta programações de disciplinas foram analisadas em dois grupos cronológicos, 1975-1981 e 1982-1990. Essa divisăo foi efetuada, em consideraçăo à modificaçăo curricular de 1981, quando o Curso de Habilitação em Enfermagem de Saúde Pública foi incorporado ao Curso de Graduaçăo através da Disciplina Enfermagem em Saúde Pública.

O procedimento de análise foi elaborado com base nas técnicas de análise de conteúdo de KRIPPENDORFF ${ }^{18}$ e consistiu de seis passos: 1)Coleta, autenticaçăo e organizaçăo dos programas das disciplinas; 2) Elaboraçăo das dimensões e instruções para análise, por pesquisador não envolvido na análise documental; 3) Codificaçăo dos itens nos ducumentos segundo as dimensões e instruções elaboradas; 4) Agrupamento, classificaçăo e categorizaçăo dos itens nas respectivas dimensões; 5) Interpretação das categorias indicando a maneira que o elemento da dimensăo se refletia no programa; e, 6) Inferência contextual, ou reexame das categorias com relaçăo aos elementos constitutivos do conceito teórico de "papel profissional".

Instruçőes e dimensões de análise foram elaboradas com base nas questőes de pesquisa, no teoria de papeis e no conhecimento das práticas da enfermagem. As mesmas foram testadas antes da sua aplicação por dois pesquisadores membros que năo participaram da sua
Ousdro 1

Concellos tobrlcos, dimenedres concenptuals evidinel.

contedidoes does progreme dee diectollinea do enformagem em eaúds publlea.

\begin{tabular}{|c|c|}
\hline Dinenelo do Anstlles & Evldinet Proeurada nos Contácidoe \\
\hline 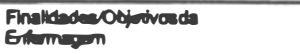 & $\begin{array}{l}\text { Reaultados deeejados ov objelivos da } \\
\text { enterm (o pare quido fazer) }\end{array}$ \\
\hline Conhecimentos TEcnico-Cientilicos & Ensino de troricas especificas \\
\hline Caracteristicas Profissionais & 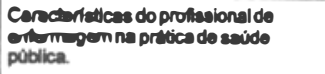 \\
\hline Velortenceses dices & $\begin{array}{l}\text { Aepectos eticos na pritica do } \\
\text { ONumegen em saúde pública. }\end{array}$ \\
\hline Acbes Assibtencinis & 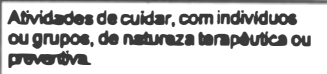 \\
\hline Acoes Educetiven & $\begin{array}{l}\text { Nividedes de ensino de conceritos de } \\
\text { eavide com individuos ou grupos. }\end{array}$ \\
\hline Acoee Administorives & $\begin{array}{l}\text { Alvidades de organieacslo de servico } \\
\text { e de gerenciamento. }\end{array}$ \\
\hline Habilidedese Destrazas & $\begin{array}{l}\text { Habilidedes no uso de equipementos } \\
\text { e aperellios eapecillose. }\end{array}$ \\
\hline $\begin{array}{l}\text { Contexto Social } \\
\text { Contexto Econdmico } \\
\text { Contexto Polltico } \\
\text { Contexto de Trabiaho } \\
\text { Contexto de Sacude }\end{array}$ & $\begin{array}{l}\text { Situecto do pals nas treas: social, } \\
\text { comonorice, polltica, de trabalho e de } \\
\text { exide. }\end{array}$ \\
\hline
\end{tabular}

elaboração. O QUADRO 1 mostra a relação entre as dimensões de análise construídas, os conceitos teóricos de origem e a evidéncia que representaria a dimensão nos conteúdos.

\section{2. "Survey" dos Enfermeiros}

Uma amostra de 99 enfermeiros egressos do Curso de 1974 a 1990 foi selecionada de forma probabilística e estratificada por ano de formatura. Sessenta (60) enfermeiros foram entrevistados, representando $61,0 \%$ da amostra planejada e $08,0 \%$ do total dos egressos do Curso. $A$ alta rotatividade nos empregos, mudanças de endereço e uma greve prolongada ocorrida nos serviços durante o período do estudo dificultaram a localizaçăo de alguns enfermeiros. Outros foram eliminados após várias tentativas sem sucesso de entrevista no local de trabalho ou na residência. Houve dificuldades também, em obter as informaçőes daqueles enfermeiros que concordaram em participar. As entrevistas eram concedidas só após várias tentativas de procura, prolongando assim, o tempo de coleta de dados. Apenas um enfermeiro se recusou a participar.

As informaçőes foram coletadas através de questionário durante entrevista realizada após 
da obtençăo do consentimento do enfermeiro, adquirido posterior à explicaçăo do estudo e de seus direitos de participaçăo. Elaborado com base nos conceitos da teoria de papeis17 e na relaçăo teórica entre conteúdo curricular e a prática, segundo BOTOMÉ.7 O questionário solicitava informaçóes demográficas e de trabalho, a opiniăo dos participantes sobre a concepçăo do enfermeiro em saúde pública adquirida no Curso, sobre a correspondéncia dessa concepçăo com as demandas do trabalho, sobre dificuldades enfrentadas com relaçăo ao seu papel no trabalho, a concepção do papel do enfermeiro frente as mudanças ocorridas no sistema de saúde; e, as suas impressões sobre o ensino de enfermagem em saúde pública no Curso. $O$ seu conteúdo foi validado por 2 enfermeiros "experts"na área e testado com um grupo de 10 enfermeiros.

As informações foram submetidas a análise de conteúdo para a elaboração das taxionomias as quais foram analisados comparativamente junto aos marcos estruturais, sociais e de saúde vigente da época para detectar os fatores que influenciaram a definiçăo do conceito emitido no ensino no período de 15 anos em estudo.

\section{RESULTADOS}

\subsection{Caracterização da Amostra de Programas e de Enfermeiros Egressos}

O QUADRO 2 mostra o número de programs examinados por disciplina e por período.

\begin{tabular}{|c|c|c|c|}
\hline Perlodo & Diselplina & No do Programes & Total \\
\hline $1975-1981$ & 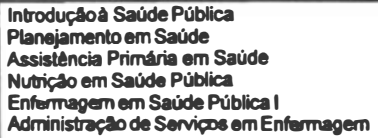 & $\begin{array}{l}9 \\
5 \\
5 \\
1 \\
5 \\
5\end{array}$ & 34 \\
\hline 1982-1990 & $\begin{array}{l}\text { Introduça a Saúde Pública } \\
\text { Enfermagem }\end{array}$ & $\begin{array}{l}18 \\
18\end{array}$ & 36 \\
\hline
\end{tabular}

A amostra de 60 enfermeiros entrevistados se caracterizou da seguinte forma: $98,6 \%$ eram do sexo feminino, a maioria casada $(58,0 \%)$ ou solteira $(37,0 \%)$ e tinham em média 33 anos de idade. A maioria ( $80,0 \%$ ) se formou no periodo
1982-1990 e 26 tinham cursado especializaçăo. Tinham, em média, 9 anos de trabalho na enfermagem, embora 15 , ou $25,0 \%$, tenham trabaIhado previamente como auxiliar, técnico ou atendente de enfermagem. As principais instituiçőes empregadoras foram as Secretarias de Saúde, estadual e municipal, a Fundaçăo Nacional de Saúde e a Universidade. O local de trabalho de $47,0 \%$ dos enfermeiros era o hospital, $23,0 \%$ trabalhavam no Centro de Saúde, ambulatório ou Nivel Central da Secretaria e 13,0\% em clínica de ensino.

\subsection{O Papel do Enfermeiro em Saúde Publica nos Conteúdos Programáticos}

\subsubsection{Período 1975-1981}

O QUADRO 3, mostra os resultados da análise de conteúdo dos programas para o período 1975-1981 e apresenta as categorias de conteúdo identificadas para cada dimensão teórica e as proporções de programas que contenham cada categoria.

Quanto à dimensão teórica Finalidade/Objetivo da Enfermagem, que representa a idéia principal mantida pelo enfermeiro com relaçăo a sua função, ou seja, o "para que"das suas açőes, os conteúdos que indicavam o repasse de conceitos ou objetivos da Enfermagem em Saúde Pública foram identificados em cada programa, agrupados e classificados. A classificaçăo dessa dimensão resultou em 9 categorias, sendo que cinco categorias foram identificadas em mais de $50,0 \%$ dos programas. Essas categorias forma: "Cuidar", "Educar", "Assistência Primária", "Controle de Doenças Transmissiveis"e "Planejamento da Assistência".

O enfoque do Curso nesses conteúdos indica que o ensino no período, 1975-1981, projetava a funçăo assisténcial e educativa do enfermeiro. A função administrativa foi representada em $44,1 \%$ dos programas. Os objetivos "Transformar a realidade"e "Intervençăo no Binômio saúde-doença", estiveram inseridos em apenas $35,2 \%$ e $8,8 \%$ dos programas, respectivamente, demostrando assim, que no 
período 1975-1981, deu-se pouca ênfase ao papel do enfermeiro como agente de mudança.

As dimensőes "Características Técnico-Científicas", "Características Profissionais" e "Características Éticas" foram consideradas como elelmentos que indicavam o perfil do enfermeiro em saúde pública projetado no Curso. Ou seja essas dimensőes representam os aspectos técnico-científicos, profissionais e éticos do enfermeiro que seriam valorizados pelo Curso.

Qusadro 3

Dimensobes coneeptuale de andilleo, catoporla identhieadas - número de programes com conteúdos comespondontes no periodo $1976-1981$ (n=34).

\begin{tabular}{|c|c|c|c|}
\hline Drneraso do Andiles & 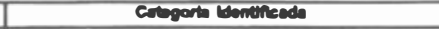 & Nor Prog. & $\bar{x}$ \\
\hline 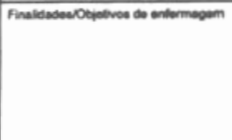 & 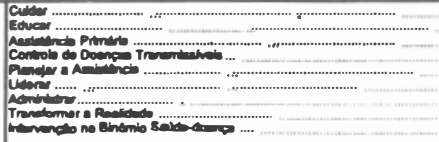 & $\begin{array}{l}29 \\
25 \\
22 \\
21 \\
10 \\
10 \\
15 \\
12 \\
03\end{array}$ & 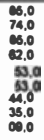 \\
\hline 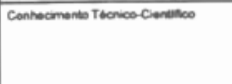 & (n) & $\begin{array}{l}10 \\
12 \\
12 \\
05 \\
\infty\end{array}$ & $\begin{array}{l}47.0 \\
35.0 \\
35.0 \\
15.0 \\
12.0\end{array}$ \\
\hline 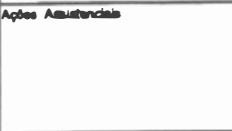 & 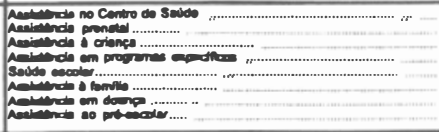 & $\begin{array}{l}24 \\
15 \\
15 \\
12 \\
10 \\
10 \\
06 \\
04 \\
0\end{array}$ & $\begin{array}{l}71.0 \\
44.0 \\
44.1 \\
35.0 \\
220.0 \\
19.0 \\
15.0 \\
12.0\end{array}$ \\
\hline 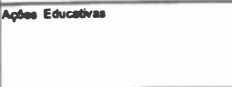 & 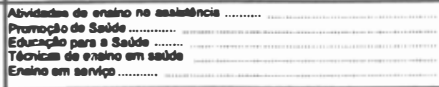 & $\begin{array}{l}25 \\
25 \\
15 \\
06 \\
05\end{array}$ & $\begin{array}{l}74.0 \\
74.0 \\
44.0 \\
24.0 \\
15.0\end{array}$ \\
\hline Apoen Naminimatratives & 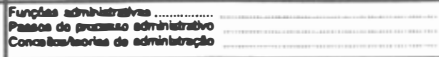 & $\begin{array}{l}07 \\
07 \\
05\end{array}$ & $\begin{array}{l}21,0 \\
21.0 \\
15.0\end{array}$ \\
\hline 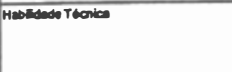 & 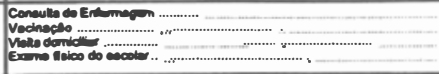 & $\begin{array}{l}29 \\
10 \\
14 \\
10\end{array}$ & $\begin{array}{l}85.0 \\
53.0 \\
41.0 \\
29.0\end{array}$ \\
\hline Combento Secial & 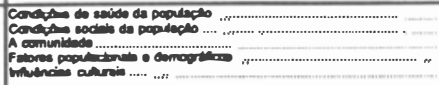 & $\begin{array}{l}0 \\
0 \\
07 \\
05 \\
04 \\
\text { of }\end{array}$ & $\begin{array}{l}24.0 \\
21.0 \\
15.0 \\
12.0 \\
12.0\end{array}$ \\
\hline Combato Econdenticos & 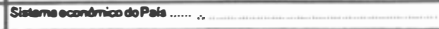 & 02 & $\infty .0$ \\
\hline Consusto Ponticos & 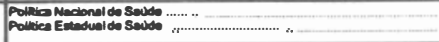 & $\begin{array}{l}07 \\
05\end{array}$ & $\begin{array}{l}20.0 \\
15.0\end{array}$ \\
\hline 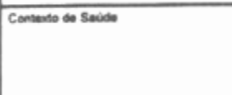 & 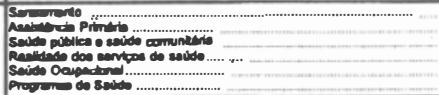 & $\begin{array}{l}12 \\
10 \\
09 \\
0 \\
07 \\
06\end{array}$ & $\begin{array}{l}33.0 \\
228.0 \\
28.0 \\
24.0 \\
21.0 \\
18.0\end{array}$ \\
\hline
\end{tabular}

"Açס̋es Assistenciais", "Açס̋es Educativas"e "Açס̋es Administrativas"e suas respectivas categorias foram identificadas num número maior de programas. Nas Açőes Assistenciais, observa-se a predominância da categoria "Assistencia no Centro de Saúde", com $71,0 \%$ dos programás tendo evidéncia desse tipo de conteúdo. Outras atividades de assistência identificadas em programas com proporçర̃es menores de $50,0 \%$, se relacionavam à assisténcia no prenatal e puericultura, em programas especificos, ao escolar è família. Este resultado vai ao encontro do enfoque do objetivo da enfermagem em Saúde Pública identificado anteriormente, onde o se enfatizou a assisténcia e a educaçăo como finalidade/objetivo das açőes do enfermeiro. As açőes assistencias no Centro de Saúde e dentro dos programas vigentes, como Prenatal, Puericultura e outros, constituiram um enfoque contínuo neste primeiro período.

As "Açőes Educativas" predominaram fortemente também nesse periodo, especialmente quanto às atividades de "Ensino na Assistência Direta"e atividades de "Promoçăo da Saúde", ambas categorias com $74,0 \%$ dos programas mostrando evidéncia ao respeito. Outras atividades focalizadas em menor número de programas foram a "Educa

Na dimensăo Características/Conhecimento Técnico-Científicos, năo houve um enfoque contínuo e forte nos conteúdos desse primeiro período, já que o número de programas que enfocaram essas categorias foram poucos, menos de 50,0\%.O conhecimento focalizado referiu-se à "Bioestística, " "Epidemiologia," "Levantamento Sócio-Sanitário, "Planejamento" e "Pesquisa." A interpretação desses resultados refere que no perído 1975-1981, o aspecto técnico do papel do enfermeiro em saúde pública predominou, especialmente nas áreas de diagnóstico sanitário e de planejamento.

Quanto ao comportamento, elemento essencial do conceito de "papel", as dimensőes de ção para a Saúde", "Técnicas de Ensino"e "Ensino em Serviço". Observa-se, porém, que, neste período, a funçăo educativa do enfermeiro priorizava a orientaçăo individual no processo da assisténcia, como mostram as duas primeiras categorias encontradas na grande maioria dos programas. $O$ ensino coletivo representado pela categoria "Educaçăo para Saúde"teve menores proporções.

Quanto às "Ações Administrativas", observase que uma porporção mínima dos programas apresentaram conteúdo que focalizava tais atividades, com apenas três categorias sendo identificadas nessa dimensão ("Funçőes Administrativas", "Passos do Processo Administrativo"e 
"Conceitos/Teorias de Administraçăo"), com apenas $15,0 \%$ a $21,0 \%$ dos programas contendo-as.

Năo se encontrou evidência do Curso ter enfatizado a responsabilidade do enfermeiro no que diz respeito ao treinamento dos profissionais de enfermagem, já que apenas 5 programas $(15,0 \%)$ fizeram menção desse conteúdo, referindo-se ao treinamento de estudantes e de grupos de voluntários em saúde da comunidade. Vale ressaltar que esse dado é questionável, já que é de conhecimento geral, que a funçăo de treinamento de grupos foi desenvolvida em grande escala durante o período da existéncia da Habilitaçăo em Enfermagem no Curso de Enfermagem. Sugere-se que os programas não registraram tal atividade como atividade/conteúdo de aprendizagem embora tenha sido amplamento desenvolvida com participação dos alunos de enfermagem.

Encontrou-se evidéncia em $85,0 \%$ dos programas, da énfase na habilidade de Consulta de Enfermagem. A destreza na vacinaçăo, visita domiciliar e exame físico do escolar foram também mencionados em menor proporções que a consulta de enfermagem. Conteúdos relacionados às características ou conhecimentos na área profissional ou ética não foram identificados nos programas.

Com relação ào"Contexto", encontrou-se evidéncia de conteúdos relacionados a alguns aspectos do contexto social, da situaçăo económica e de saúde, tanto política como da realidade de saúde da época. Porém, o que se observa é que o Contexto Saúde foi mais enfatizado nesse período, com percentuais nas suas categorias geralmente maiores que as das dimensões de contexto social, económico e/ou político. Assim, os conteúdos que tratavam da realidade de saúde, concentraram-se nas situaçőes de saneamento, da assisténcia primária prestada à populaçăo, da saúde pública em geral e da em enfermagem em saúde pública, assim como da realidade dos serviços de saúde quanto a sua estrutura organizacional, funcionamento, planejamento sanitário e programas de saúde vigentes.

Os conteúdos referentes ao Contexto Social, cujas categorias apresentam percentuais sig- nificativos, aparecem, nesse período, destacando as condições de saúde e sociais da pupulaçăo, ou seja as problemáticas dos diversos grupos populacionais (grupo materno infantil, escolar), os fatores determinantes do bem estar social e a escola como instituiçăo social. Ressalta as características dos problemas de saúde em paises mais e menos desenvolvidos. Embora encontrou-se evidéncia de que os conteúdos desse período trataram as questőes relacionadas à comunidade como contexto (organização, desenvolvimento, e local de trabalho), à populaçăo (política populacional, crescimento, composição, movimento e migração no ambito nacional) e o contexto cultural com relaçăo à saúde, esses conteúdos foram encontradas em percentuais menos significativos, demonstrando que esse enfoque năo foi consistente nesse período.

No Contexto Político, conteúdos sobre o sistema nacional de saúde e sobre as diretrizes gerais e a estrutura básica de saúde do Estado foram abordadas em $20,0 \%$ e $15,0 \%$ dos programas nesse período respectivamente. Abordagem das questões relacionadas ao Contexto Económico foi ainda mais limitada, com apenas $6,0 \%$ dos programas apresentando conteúdo nesse aspecto. Os programas desse periodo năo apresentaram conteúdos que trabalhassem as questőes de Contexto de Trabalho do enfermeiro, embora referiram tratar das questões dos serviços de saúde e da atuação do enfermeiro na assisténcia primária de saúde. Vale ressaltar que a terminologia relacionada ao processo de trabalho em saúde aparece na literatura de enfermagem em referéncia à prática do enfermeiro no início da década de 80 , portanto, a ausência de referência ao respeito é compreensível.

\subsubsection{Período 1982-1990}

Como se observa no QUADRO 4, no periodo 1982-1990, o enfoque da Assisténcia como Finalidade/Objetivo da enfermagem persiste, com $86,0 \%$ dos programas apresentando tal conteúdo. Porém, tal assistência se apresenta nesse período, inerente aos programas gover- 
namentais (veja as categorias de Açőes Assistenciais). A "Ássistência Primária" destacou-se em apenas $39,0 \%$ dos programas nesse segundo período.

Observa-se também, um objetivo diferente em destaque, "Análise das Políticas de Saúde," com $100,0 \%$ dos programas mostrando evidéncia desse conteúdo. Paralelo a isto, o percentual de programas que apresentaram as categorias "Envolvimento social" e "Desenvolvimento da Comunidade" como Finalidade/Objetivo da Enfermagem, também foram significativos em termos proporcionais $(78,0$ e $56,0 \%$ respectivamente). Isso é interpretado como sendo uma reflexăo do interesse em projetar o objetivo assistencial da enfermagem, paralelo ao desenvolvimento da consciéncia dos problemas sociais e de saúde que atingem as comunidades. Representa uma conceituação mais ampla do papel do enfermeiro em saúde pública, uma vez que inclui dentro da finalidade de enfermagem o desenvolvimento da comunidade $e$ as finalidades de bem estar social mais abrangentes assim como o conhecimento mais aprofundado das políticas de saúde vigentes. Porém, não foi possível detectar se essa relaçăo assistência-consciência social se desenvolviam conjuntamente com é de se pensar ao encontrar ambos conteúdos aparecendo na maioria dos programas desse período.

Em relação aos aspectos técnicos valorizados nesse período, a maioria dos programas $(64,0 \%)$ refletiram "Características TécnicoCientificas"de um profissional capacitado para planejamento em saúde, mas centralizadas nas normas e estratégias de planejamento e programação. A preparaçăo técnica no uso de bioestatística, técnicas introdutórias, estudos epidemiológicos e vigilância epidemiológica foram categorias também identificadas, embora em menor proporçăo no período 1982-1990 (QUADRO 4).

Assim, os aspectos técnico-científicos enfocados nas disciplinas foram as técnicas e estratégicas de planejamento em saúde e epidemiológicas para o controle de doenças, e em segundo lugar, as técnicas de pesquisa. Dessa forma, os conteúdos nas disciplinas projetaram o enfermeiro em saúde pública, como planejador capaz de participar do processo de planejamento em saúde e ná área de vigilância epidemiológica, mas com conhecimento rudimentar sobre o processo científico de investigação.

$\mathrm{Na}$ dimensăo "Açőes Educativas", a atividade "Educaçăo para a Saúde"persistiu nesse período, com $52,0 \%$ dos programas mostrando tal conteúdo. A ação de "Administração do Serviço 1982-1990. Já as "Habilidades/destrezas" identificadas se relacionam à vacinaçăo e à visita domiciliar, embora o percentual de programas com tais conteúdos foi mínimo neste período.

Com relaçăo as dimensões de "Contexto", se observa que no período 1982-1990, destacaram-se os conteúdos que tratavam de questőes da realidade social e política, já que as categorias em ambas dimensర̋es apresentaram frequências acima de $50,0 \%$, ou seja, a maioria dos programas nesse periodo ressaltaram tais aspectos. Aspectos do Contexto social enfatizados referiram-se à comunidade como grupo social (organizaçăo, desenvolvimento, trabalho comunitário e barreiras), as condiçס̃es sociais como pobreza, desemprego, etc. em relação aos problemas de família e de grupos especificos e a relaçăo do modo de produçăo na sociedade com a saúde. Outros aspectos tais como determinantes sociais na história natural da doença, situação populacional do país e os aspectos das condiçőes de saúde da populaçăo em relaçăo aos contextos de serviços de saúde foram abordados em um número reduzido de programas nesse período.

Quanto ao Contexto Político, mais de 50,0\% dos programas nesse período apresentaram conteúdos que referiram o estudo da Política Nacional de Saúde e os planos de desenvolvimento em saúde do Brasil em relaçăo ao planejamento da enfermagem. Outros aspectos tais como a política de saneamento e tendéncias nos programas gevernamentais de saúde foram citados em um número limitado de programas. Da mesma forma a política da reforma sanitária como conteúdo em estudo apareceu em apenas $22,0 \%$ dos programas, embora o movimento tenha sido efetivado desde 1987, ou seja, era 
de se esperar que um número maior de programas do período 1987 a 1990 abordassem tal conteúdo.

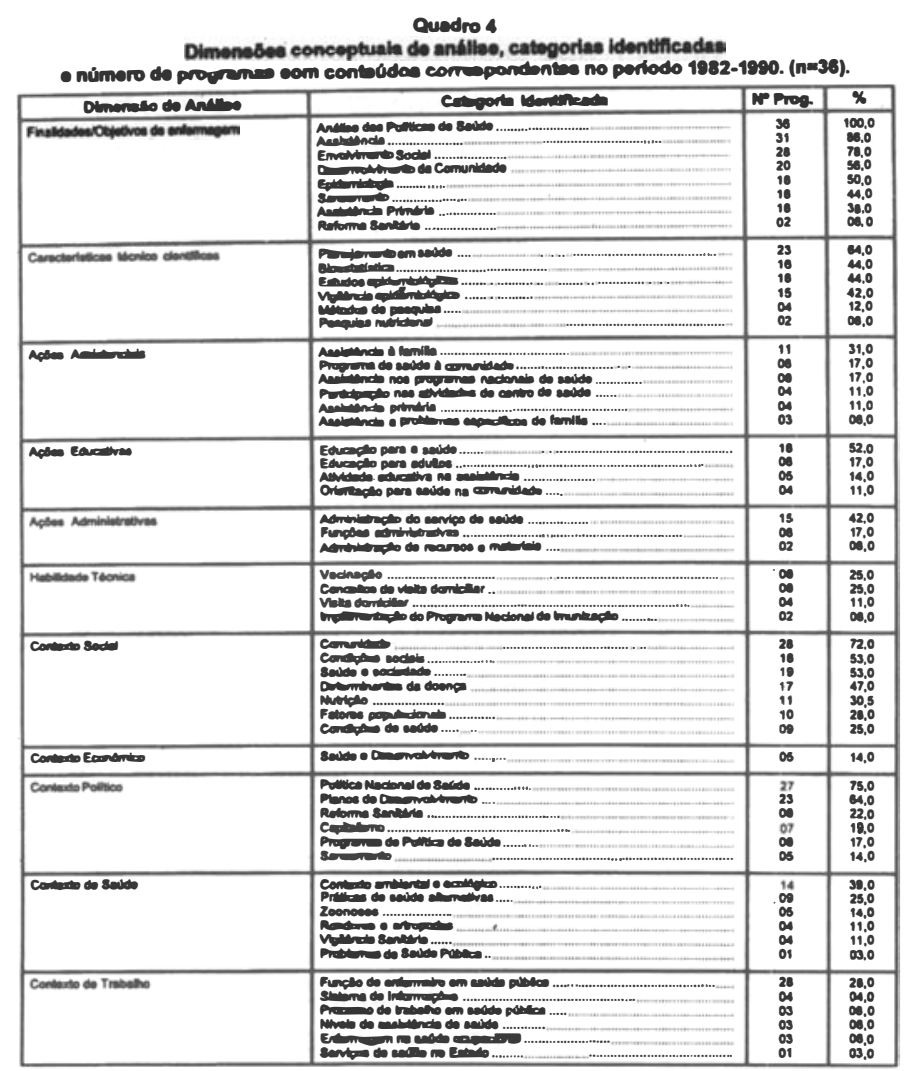

ram características específicas da função do enfermeiro na sua participaçăo no sistema de informações através dos mapas diários de atividades, registros compulsórios, etc. Neste período também, observa'se o início de reflexões sobre os elementos do trabalho do enfermeiro, e introduz'se terminologia ao respeito; o objeto e os instrumentos do trabalho da enfermagem, e o mercado de trabalho em saúde pública nos serviços de saúde do Estado. As dimensões relacionadas à Ética e aos aspectos Profissionais năo foram identificadas nos conteúdos deste período.

Assim, a realidade de trabalho do enfermeiro aparece nos conteúdos apenas no sentido de preparar o aluno para realizar as funçőes exigidas na unidade de saúde e menos na perspectiva de uma análise crítica da situaçăo de trabalho na elaboração de abordagens que propiciassem transformaçőes.

\subsection{Concepções do Enfermeiros Egressos}

\subsubsection{O Trabalho dos Enfermeiros}

As descriçőes das atividades desen-

As categorias Contexto Económico, Contexto de Saúde e Contexto de Trabalho apareceram em menos de $50,0 \%$ dos programas, mostrando que esses conteúdos foram menos consistentes nesse período. Os planos económicos e sua relação com saúde foi encontrado em apenas $14,0 \%$ dos programas que focalizaram mais a sua evolução histórica. Já o Contexto de Saúde foi amplamente representado neste período, com conteúdos que abordaram a situação de saúde do ponto de vista ambiental, enfatizando os aspectos de saneamento e năo tanto as doenças de saúde pública como eixos populacionais.

O Contexto de Trabalho se fez presente nos conteúdos sobre a realidade de trabalho do enfèrmeiro em saúde pública, onde se apresentavolvidas pelos enfermeiros egressos no empregao foram classificadas quanto ao tipo de processo de trabalho que representavam (TABELA 1).

Tabola 1

Tipos de processos de trabalho exercidos pelos enfermeiros egressos do Curso de Enfermagem na UFRN $(n=60)$.

\begin{tabular}{|l|c|c|}
\hline \multicolumn{1}{|c|}{ Processo de Trabalho } & Enformeiros & $\%$ \\
\hline Administrar & 47 & 78,0 \\
Cuidar & 43 & 72,0 \\
Controlar Doenças Transmissiveis & 14 & 23,0 \\
Educar para Saúde & 09 & 15,0 \\
Ensinar & 09 & 15,0 \\
Produzir Conhecimentos & 02 & 03,0 \\
\hline
\end{tabular}

Encontrou-se que os processos de trabalho sendo desenvolvidos pelos enfermeiros foram Administrar (78,0\%), Cuidar $(72,0 \%)$ e Controle de Doenças Transmissíveis $(23,0 \%)$. Outros 
processos tais como Educar para a Saúde, Ensinar e Pesquisar foram identificados em um índice menor de enfermeiros, de 03,0 a $15,0 \%$. Observou-se, porém, que a maioria dos enfermeiros desenvolvem vários processos de trabalho no emprego. Poucos săo os que citaram exclusivamente um tipo de processo: 11 disseram administrar, 5 ensinar, 4 cuidar e 1 realiza controle de doença. Dessa forma, a maioria, 37 $(61,0 \%)$ dos enfermeiros descreveram seu processo de trabalho como de Administrar e Cuidar, simultaneamente e em combinaçăo com outros.

\subsubsection{O Papel do Enfermeiro em Saúde Pública no Curso}

As descrições dos enfermeiros quanto ao papel do enfermeiro em saúde pública projetado no Curso resultou nas seeguintes classificaçőes correspondentes à Finalidade/Objetivo da Enfermagem.

Tabola 2

Proporçto de enfermeiros egresesos, segundo suas concepcóes das finalidado/objotivo do enformoiro em saúde pública projetades no Curso de Enfermagem na UFRN (n=60).

\begin{tabular}{|c|c|c|}
\hline Objettvo / Finalidade & Enfeŕmolros & $\%$ \\
\hline Prevençâo/Educaçâoem saúde & 23 & 38,0 \\
\hline Saúde da Comunidade & 11 & 18,0 \\
\hline Assistência Primária & 08 & 13,0 \\
\hline Gerência/Administraçăo & 03 & 05,0 \\
\hline Vigilância Sanitária & 03 & 05,0 \\
\hline TransformacablMudança & 03 & 05,0 \\
\hline Concepcăo nâo especificada/Sem resposta & 16 & 27,0 \\
\hline
\end{tabular}

Esses resultados mostram uma concepçăo restrita do papel do enfermeiro em saúde coletiva, pois, embora tenham como foco de açăo a prevençăo, essa funçăo educativa se limita ao contexto das atividades assistenciais no Centro de Saúde. A visăo mais ampla do papel transformador, ou do enfermeiro como agente de mudança, foi referida por pouquíssimos participantes $(05,0 \%)$. Embora alguns criticaram o papel político enfatizado no segundo período, a maioria năo expressăo insatisfaçăo com tal conteúdo.

Outro resultado marcante foi o grande número de enfermeiros $27,0 \%$ que năo conseguiu dar uma conceituaçăo. Alguns desses apontaram deficiéncias no Curso como explicaçăo principal dessa falha.

\subsubsection{Corespondência da Concepção Projetada no Curso com a Prática}

As respostas à pergunta se a concepçăo do papel do enfermeiro em saúde pública adquirida no Curso teve correspondéncia às expectativas funcionais quando da inserçăo no mercado de trabalho foram classificadas em respostas positivas, negativas e regular. Trinta $(50,0 \%)$ enfermeiros responderam de forma positiva, 27 (45,0\% negativamente e $3(05,0 \%)$ não responderam.

Os enfermeiros com opinião positiva enfatizaram as atividades exigidas no serviço de prevençăo e educaçăo em

A categoria com maior representação nas descrições foi a de "Prevenção/Educação em Saúde", como mostra a TABELA 2. Contudo, essa categoria reflete uma visão funcionalista, pois as atividades especificadas como referentes a esse papel são específicas para grupos ou programas especiais e focalizam a doença. Eis algumas das descrições nessa categoria: "orientador e educador(..). prevenir certos tipo de doença..", "orientação à populą̧̧ão sobre como prevenir doenças". Dez porcento dos enfermeiros abordaram o aspecto coletivo do papel do enfermeiro na prevençăo e apenas duas descrições referiram o conceito de promoçăo da saúde. saúde, na assistência e na supervisăo, como sendo compatíveis com o papel educativo enfatizado e adquirido no Curso. Outros apontaram correspondéncia embora trabalhavam no ambiente hospitalar, indicando a possibilidade do pensar em saúde pública mesmo na instituiçăo hospitalar. Numa perspectiva incoerente, alguns enfermeiros citaram a realidade caótica e desorganizada dos serviços como correspondentes ao ensino: "na prática o modelo àssistencial era de trabalho parcelado e isolado, e o professor e os enfermeiros desempenhavam apenas estas atividades(..). havia coerência".

Afirmações tais como: "encontramos dificuldades na estrutura de toda a Unidade(..). mais 
com perseveráncia e boa vontade dá para pór em prática nosso trabalho", demostram uma postura de abnegaçăo dos enfermeiros frente as incoeréncias existentes nas realidades de trabalho. A maioria também afirmou sentir-se desafiado com as exigências do serviço.

Os enfermeiros que responderam negativamente referiram o despreparo técnico sentido e a incoeréncia entre a teoria e a prática existente como justificativa:

"muito confusa pelas coisas que tinha visto na Universidade e as funçס̋es desempenhadas no posto. Na Universidade detem-se muito na teoria sobre política de saúde, questóes críticas de saúde, mas sobre as práticas desempenhadas no posto ficou muito a desejar";

"Durante o curso a imagem transmitida é uma, na prática a realidade é outra, digamos que oposta (...)depende muito da capacidade do profissional, uns demonstram que suas qualificaçőes são muitas e que precisará de se impor diante de muitos obstáculos".

\subsubsection{Dificuldades de Ingresso no Trabalho}

Insegurança técnica e condiçőes de trabaIho inadequadas foram os principais dificuldades identificada pelos enfermeiros $(58,0 \%$ e $35,0 \%$ respectivamente), quando confrontadas com as expectativas da instituição empregadora. Eis alguns depoimentos:

"me senti perdida, cheia de ansiedade $e$ de medo. Não conhecia meu papel dentro da instituição, que me fazia ficar insegura quando tomava atitudes inicias (será eu,[sic] é este meu papel?) Devo realmente fazer isto, ou estou tomando o lugar dos outros profissionais? Isto foi péssimo, pois atrapalhava meu serviço"

"baixos salários e falta de conscientização dos profissionais para as reivindicaçőes justas"

Em geral, os enfermeiros citaram que resolveram suas dificuldades com muito esforço e estudo individual através de capacitaçőes técnicas obtidas nos serviços ou em estágios e cursos nas áreas específicas.

\subsubsection{O Papel do Enfermeiro de Saúde Pública Frente as Mudanças no Setor Saúde}

Para detectar se as concepç̋̊es dos enfermeiros ao respeito do papel do enfermeiro em saúde pública tinham mudado em funçăo da experiência adquirida e das exigências atuais do sistema de saúde que exige a definiçăo de novos papeis dos profissionais de saúde, se perguntou aos enfermeiros qual era a sua concepçăo atual. As classificações encontram-se na Tabela 3.

A maioria das concepções derivadas das respostas a este questionamento săo de natureza

Tabola 3

Distribulflo dos egreseos segundo suas concops6es do papel do enfermoiro do saúde públles fronts as mudanças ocorridas no setor saúde.

\begin{tabular}{|c|c|c|}
\hline Finalidade / Objetvo do Enfoimeiro & Entermeiros & $\mathbf{\%}$ \\
\hline Provencado/Educacalomsaude & 16 & 27,0 \\
\hline SaúdedaComunidade & $\dot{\infty}$ & 10,0 \\
\hline Diverso/Amplo & $\infty 6$ & 10,0 \\
\hline Intermediaça da Polltica em Saúde Vigente & 04 & 07,0 \\
\hline Assistencia Primária & 03 & 05,0 \\
\hline Mudança Transformacao & 03 & 05,0 \\
\hline Liderar & 03 & 05,0 \\
\hline Assistencia curativa & 03 & 05,0 \\
\hline Administraça & 01 & 02,0 \\
\hline ReproduziroSenvico & $\infty$ & 03,0 \\
\hline Resposta sem concepsas $/$ Nấ respondeu & 14 & 23,0 \\
\hline TOTAL & 60 & 100,0 \\
\hline
\end{tabular}

preventiva, com categorias intituladas "Promotor/ educação em Saúde"e "Saúde da Comunidade". Em seguida, predominou a visão do enfermeiro condisente à política de saúde, com $07,0 \%$ dos enfermeiros referindo esse papel. A função assistencial tipo "Assistência Primária"e "Assistência curativa"enquadrou apenas $10,0 \%$ dos profissionais. As concep̧̧őes do enfermeiro como lider dentro de uma papel mais direcionado a mudanças foi encontrado em algumas descrições. Ainda, $16(27,0 \%)$ valorizam o enfermeiro em saúde pública no contexto atual da Reforma Sanitária e destacam o "status" profissional adquirido:

"somos essenciais e importantes no desenvolvimento do programa de assistencia à comunidade a nível primário" 
"esta fazendo parte do processo decisório a nível da secretaria"

Um número significativo $(23,0)$ de enfermeiros năo souberam expressar sua concepçăo, ou se recusaram a responder, demonstrando mais uma vez, a sua dificuldade em conceituar.

Observa-se nesses resultados que as concepções dos enfermeiros permanecem atreladas às funções educativas e de prevençăo, mesmo após a experiéncia adquirida na prática. Existe, porém, uma tendéncia para a promoçăo da saúde na categoria de "Saúde da Comunidade" e para uma valorizaçăo da categoria entre os enfermeiros, demonstrando assim uma ligeira mudança dos conceitos iniciais do grupo.

\subsubsection{O Ensino de Enfermagem em Saúde Pública na UFRN}

Tabola 4

Distribulçlo dos egreesos segundo suas oplnibes sobro o ensino de onformagem em saúde públlea no Curso do Enfermagem na UFRN.

\begin{tabular}{|l|c|c|}
\hline \multicolumn{1}{|c|}{ Oplnile } & Fa & \% \\
\hline Positiva & 24 & 40,0 \\
Regular & 18 & 30,0 \\
Negasiva & 17 & 28,0 \\
Sem Opiniso & 01 & 02,0 \\
\hline TOTAL & 60 & 100,0 \\
\hline
\end{tabular}

Uma proporçăo maior de egressos expressou opiniőes positivas sobre o ensino de enfermagem em saúde pública no Curso, como mostra a Tabela 4. As opiniőes positivas foram expressas por afirmações tais com "Bom", "Excelente", "Proveitoso", "Gostei”, etc., sendo que a maioria desses enfermeiros năo explicou porque achou o curso proveitoso. Exemplos dos comentários que acompanharam algumas das opiniões favoráveis ao Curso săo apresentados no QUADRO 5 segundo os aspectos considerados positivos.

Como se obseva no QUADRO 5, os enfermeiros que opinaram de formas positiva sobre o ensino, se referiram aos aspectos de mudança sentida na formaçăo de conceitos preventivos e comunitários, ou seja, sen- tiram uma mudança de visăo da enfermagem, o despertar para a importância da saúde pública e a aquisição de conhecimentos de pesquisa. Vale ressaltar que, embora esses enfermeiros tenham opinião positiva quanto ao ensino, também salientaram a carga horária insuficiente para a prática como principal deficiência.

Nas opiniőes classificadas como Regular, obsevou-se que, embora os enfermeiros iniciavam suas respostas com afirmaçőes positivas ou um tanto neutras, com frases tais como "Bom, mas...", "Poderia ter sido melho", "Tivemos algumas dificuldades", eles apontaram também algumas deficiências nas suas respostas, demonstrando assim uma tendéncia para insatisfação com o Curso. Os aspectos ressaltados pelos enfermeiros indicam as deficiências tais como a desintegração teoria-prática e carga horária insuficiente para a prátiva (QUADRO 6). As sugestőes emitidas por este grupo focalizaram a necessidade de tornar a prática mais real e significativa para o aluno e a integração do ensino à prática, assim como maior carga horária para a prática.

As percepçőes Negativas sobre o ensino de enfermagem em saúde pública no Curso expressadas por $28,0 \%$ dos egressos entrevistados, foram identificadas através das afirmações que denotavam insatisfaçăo definitiva, tais como "deficiente", "năo proveitoso", "limitado", "falho", "fraco" etc. e quando delineavam as deficiéncias. As deficiências citadas săo apresentadas no QUADRO 7.

Como se observa no Quadro 7, os enfermeiros criticam o ensino de saúde pública, pela sua

Aspectos proventoecs epontedos por uns cogressos com opinilo postiva

\begin{tabular}{|c|c|}
\hline ASPECTOS POSITIVOS & OPINLĀO \\
\hline Aquisichto de Nove Visto de Enfermagem & 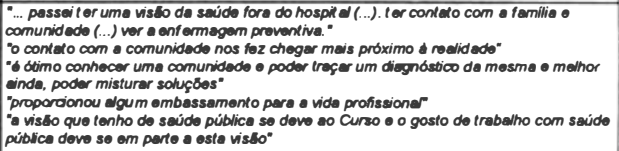 \\
\hline Valorizaçấo da Saúde Pública & 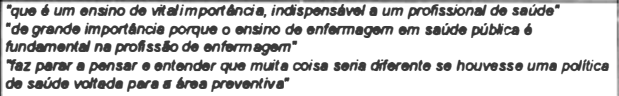 \\
\hline Ampliachio de Conhecimentos & 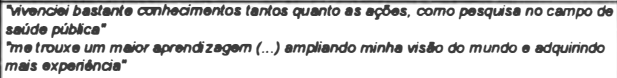 \\
\hline Estimulo dos Professores & $\begin{array}{l}\text { "pepel faciliedor dos professores estimulau a nós estud antos" } \\
\text { "oxiste interesse por perte dos professores" }\end{array}$ \\
\hline 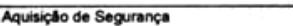 & "contribuiv am müto pare que possa desempenher as minhes fungles com segurança" \\
\hline
\end{tabular}




\begin{tabular}{|c|c|}
\hline Aspecto Meaptivo & Opinilso \\
\hline Desintegrasklo ensino-prttica & 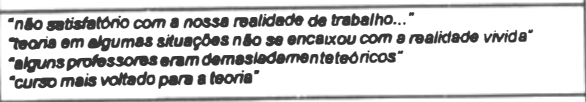 \\
\hline Carga Hordria Insuficiente & 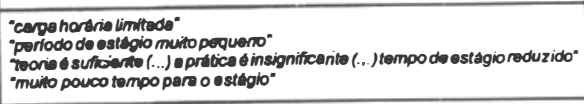 \\
\hline Ms Oualidede do Ensino & 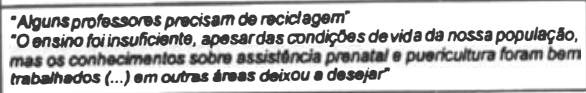 \\
\hline
\end{tabular}
egressos do primeiro período (TABELA 5) refletem ações de ordem assistenciais e educativas correspondendo com as finalidades encontradas nos conteúdos desse periodo. Tais atividades refletem uma tendéncia à assistencia indi-

desintegração entre a teoria e pela qualidade do ensino em si, caracterizandoo como muito superficial. Carga horária insuficiente aparece também nessas descrições, assim como a falta de estrutura nos cam-

Tabola 6

Proporcbes de programas e entormelros conesesos no pertodo 1982-1980, segundo a finalladadobjetivo do enformolro em saúde públlea no Curso do Enformagem / UFRN.

\begin{tabular}{|c|c|c|c|c|c|}
\hline FInalidade/Objetivo & $\begin{array}{l}\text { Pro } \\
\text { grames } \\
\text { (n=34) }\end{array}$ & \% & FInalidade/Objetivo & $\begin{array}{l}\text { Enfor- } \\
\text { meiros } \\
(n=12)\end{array}$ & $\%$ \\
\hline Analise das Pollticas de Gaúde & 36 & 100,00 & Saúde da Comunidade & 18 & 38,0 \\
\hline Assistencia (Cuidar) & 31 & 86,0 & Educaçäo em Saúde & 10 & 21,0 \\
\hline Envolvimento com Aspectos Sociäis & 28 & 78,0 & Prevengasoda Doenga & 05 & 10.0 \\
\hline DesenvolvimentodaComunidade & 20 & 56.0 & Assistencia (Programas Especiais) & 04 & 08,0 \\
\hline Epiderniologia & 18 & 50,0 & Atendimento nas unidades de saúde & 04 & 08,0 \\
\hline Saneamento & 16 & 44,0 & Administracso & 03 & 06,0 \\
\hline Assistencia Primaria & 18 & 39,0 & Controle de DT? Vig. Sanitária & 03 & 06,0 \\
\hline Reforma Sanitaria & 02 & 06,0 & & 16 & 33,0 \\
\hline
\end{tabular}
pos práticos. Esses enfermeiros năo se sentem preparados para enfrentar a prática, uma vez que acreditam que o ensino não Ihes deu segurança para a vivência da realidade.

vidual, na medida que se referem a programas especiais de saúde na unidade.

Já no segundo período, de 1982-1990 (TA-

Quadro 7

Deficiencias do ensino ressaltadas pelos 17 egressos com opinila negativa sobre o ensino de enfermagem em saúde pública no Curso de Enfermagem da UFRN no periodo 1974-1990

\begin{tabular}{|c|c|}
\hline DEFICIENCIA & OPINIAOO \\
\hline Desintegraçăo Teoria-Prática & $\begin{array}{l}\text { "o que se ve na teoria nốo ó o que se encontra na prática" } \\
\text { "o que vivenciei (...) ficou apenas das minhas experiéncias e longe de se compartilhar } \\
\text { com as reais necessidades" } \\
\text { "a Escola de Enfermagem na prárica é muito contraditória" } \\
\text { "a escola passa conteúdo que na prática vivenciada existe inúmeras contradiçóes (...) a } \\
\text { escola segue uma teoria (politica de saúde) e a instituiçáo segue outra, (teoria voltada } \\
\text { para os interesses politicos partidários)..." }\end{array}$ \\
\hline Má Qualidade do Ensino & 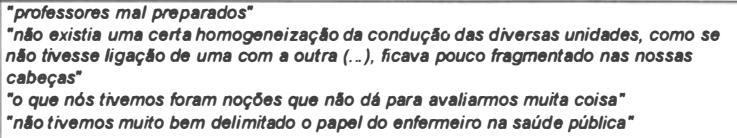 \\
\hline Carga Horária Insuficiente & $\begin{array}{l}\text { "acho muito limitador (...) carga horária restrita (...) em determinado momento alienaste" } \\
\text { "a vinencia foi muito limitadoras dificuldades eram grandes" } \\
\text { "periodo muito curto para que se possa fazer alguma coisa realmente e sentir efeito" } \\
\text { "ficamos na vontade, no desejo (...) o tempo de aprendizado (nesta área) o muito curto } \\
\text { nł́o dá para desenvolver um bom trabalho" }\end{array}$ \\
\hline Falta de Estrutura & $\begin{array}{l}\text { "locais ndo estruturados para comportar a atuaçấ dos professores" } \\
\text { "campo de estágio muito restrito" }\end{array}$ \\
\hline Desestimulante & $\begin{array}{l}\text { "faltava estimulo (... ) transmitia uma visåo restrita do que seria saúde pública" } \\
\text { "faltava incentivo, motivaçăo" }\end{array}$ \\
\hline
\end{tabular}

Tabela 5

Proporebes de programas e enfermelros egressos no periodo 1974-1981, ceoundo a Rnalldade/objetlvo do enfermelro em saúde pública no Curso de Enfermagem I UFRN

\begin{tabular}{|c|c|c|c|c|c|}
\hline ObjetIvo/FInalldade & $\underset{\substack{\text { gramas } \\
(n=34)}}{\text { Pro- }}$ & $\%$ & Objettvo/Finalldade & $\begin{array}{c}\text { Enfor- } \\
\text { meiros } \\
(n=12)\end{array}$ & $\%$ \\
\hline $\begin{array}{l}\text { Cuidar } \\
\text { Educar } \\
\text { Assistoncia Primária } \\
\text { Controle de D.T. } \\
\text { Planejar a Assistência } \\
\text { Liderar } \\
\text { Administrar } \\
\text { Transformara Realidade } \\
\text { Intervençäo na Saúde e na Doença }\end{array}$ & $\begin{array}{l}29 \\
25 \\
22 \\
21 \\
18 \\
18 \\
15 \\
12 \\
03\end{array}$ & $\begin{array}{l}85,0 \\
74,0 \\
65,0 \\
62,0 \\
53,0 \\
53,0 \\
44,0 \\
35,0 \\
09,0\end{array}$ & $\begin{array}{l}\text { Saúdeda Comunidade } \\
\text { Educaçâa em Saúde } \\
\text { Prevençadoda Doença } \\
\text { Assistencia (Programas Especiais) } \\
\text { Atendimento nas unidades de saúde } \\
\text { Administraçâ } \\
\text { Controle de DT? Vig. Sanitária }\end{array}$ & $\begin{array}{l}06 \\
05 \\
05 \\
02 \\
02 \\
01 \\
01\end{array}$ & $\begin{array}{l}50,0 \\
42,0 \\
42,0 \\
17,0 \\
17,0 \\
08,0 \\
08,0\end{array}$ \\
\hline
\end{tabular}

BELA6), se observa nas finalidades dos enfermeiros uma tendência para o trabalho coletivo dentro de uma visão mais comunitária como demonstram as ações de prevenção e promoção em saúde. Nota-se também, tanto nos conteúdos como nas concepções dos enfermeiros, objetivos mais sociais em saúde, como a transformação e mudança no setor, embora pouco frequentes. Nos conteúdos, predomina a análise das políticas de saúde e envolvimento com aspectos sociais. A função assistencial continua forte, porém, com $86,0 \%$ dos programas refletindo tal enfoque. Contudo, o trabalho na comunidade 
nos aspectos epidemiológicos e de saneamento såo mais enfatizados neste periodo que o anterior e a assisténcia primária deixa de ser destaque nesse período.

\section{DISCUSSÃO}

\subsection{Características do Papel do enfermeiro em Saúde Pública nos Conteúdos Pro- gramáticos do Curso de Enfermagem da UFRN, 1974-1990 e seus determinantes.}

Observa-se nos resultados sobre as características do papel do enfermeiro em saúde pública projetado no Curso, que o ensino de saúde pública tem, em geral, focalizado valores assistenciais, educacionais e administrativos referentes à funçăo do enfermeiro em saúde pública. Os comportamentos ressaltados são de natureza cognitiva, ou seja em forma de conhecimentos técnico-científicos, em detrimento dos comportamentos profissionais, éticos e técnico-práticos que deveriam acompanhar a socialização do enfermeiro no papel. Observa-se também, uma diferença entre os dois períodos, 1974-1981 e 1982-1990, nas características do papel do enfermeiro enfatizado no Curso, especificamente nas açőes assistenciais, educativas e administrativas.

No período 1975-1981, o enfoque de ensino se deu nas atividades da assistência individual e institucionalizada, representado nos altos índices de programas que apresentaram conteúdos relacionadas às Atividades de Assisténcia no Centro de Saúde, no Pre-Natal, Assisténcia à criançá e em programas específicos (QUADRO 3). Já no período 1982-1990, os conteúdos predominantes enfocaram ações coletivas fora da instituiçăo, tais como Assistência à Família e Trabalho na Comunidade. A proporção de programas que apresentaram essas categorias, porém, é relativamente pequena quando comparada aos indices das categorias mais frequentes do periodo anterior. Os enfoques das ações educativas identificadas em ambos periodos focalizaram à promoção de saúde e a educaçăo em saúde no processo de assisténcia, sendo mais consistentes nos primeiros anos do
Curso. Na área administrativa, os conteúdos identificados nos dois periodos săo semelhantes, como por exemplo nas funçőes administrativas, adminnistraçăo de serviços e de recursos e materiais. Encontrou-se, porem, que no primeiro período tais conteúdos referiram aspectos teóricos enquanto no segundo, referiram ações específicas de administraçăo, tais como atividades de administração do serviço no qual foram mais representadas (QUADRO 4).

Esses resultados mostram que as ações assistenciais e educativas do enfermeiro em saúde pública focalizadas nas disciplinas tem sofrido mudanças através do tempo, sendo as individuais e institucionais priorizadas nos primeiros anos do Curso de Enfermagem, e atividades de atingimento coletivo tanto na área assistencial como educacional e administrativa nos últimos anos.

Ao refletir os contextos sócio-políticos em saúde dos dois periodos na procura de uma explicaçăo para tais valorizações, observa-se que as políticas de saúde vigentes, demonstram características e enfoques similares. No periodo 1974-1981, após vários anos de mudanças políticas orientadas para esse fim, observa-se claramente um enfoque político nacional na assistência individual. De 1976 a 1979, por exemplo, o modelo de assisténcia vigente é o assistencial privatista, com a criaçăo do Sistema Nacional de Saúde (SNS) em 1975 e o Sistema Nacional de Previdéncia Social (INPAS) em 1977, que designam as ações básicas de saúde pública para o Estado e a atuação médica para o setor privádo.

Porém, em consequéncia aos vários problemas de ordem social e da óbvia exclusăo de parcelas expresas da populaçăo da assistência à saúde pelo "complexo previdenciário", (22,p.247) políticas compensatórias foram empreendidas na área da saúde durante esse período. Entre elas, a mais marcante, é a adesão do Brasil, através da $7^{\mathrm{a}}$ Conferéncia Nacional de Saúde em 1980, à proposta internacional acordada em Alma Ata de saúde para todos até o ano 2000, que utiliza como estratégia, a atenção primária de saúde, dirigida às populações marginalizadas através da oferta de tecnologia 
simples e barata. A politica de extensão de cobertura através das regionalizaçőes administrativas surge nesta época através do Programa de Interiorizaçăo das Açőes da saúde e Saneamento (PIASS) em 1976, assim como a universalizaçăo das unidades primárias de saúde através do Progrma Nacional de Serviços Básicos de Saúde (PREVSAÜDE) em 1976. ${ }^{22}$ Esse enfoque político é compartilhado pela enfermagem e as ações de atençăo primária săo também priorizados na prátiva do enfermeiro. ${ }^{4}$ Assim, nos anos 1972-1974, a OPAS passa a incentivar o treinamento em atençăo primária e a definição das funções do enfermeiro em nessa área ${ }^{5}$ Discorrendo sobre o tema "O enfermeiro e os serviços básicos de saúde" por ocasião do $33^{\circ}$ Congresso Brasileiro de Enfermagem realizado em Manaus em 1981, BORGES afirma

"A abrangência do Programa Nacional de Serviços de saúde(..)induz à concepção lógica de que os enfermeiros e outras categorias de enfermagem devem constituir o maior grupo para provisão de assistência primária de saúde"6 (p.53).

E conclama a categoria a refletir e se conscientizar no papel que tem a exercer dentro dessa visão de atenção primária nos serviços de saúde.

Dessa forma, o enfoque do ensino em saúde pública nos cursos de enfermagem nos seus primeiros 15 anos de existéncia reflete o contexto sócio-político e de saúde da época representado pela importância dada às ações básicas de saúde e especificamente aos princípios da Atenção Primaria à Saúde no currículo da Habilitação em Enfermagem em Saúde Pública.

Já no meado dos anos 80 , paralelo à mobilização popular de apoio às eleições diretas para presidência da república, inicia-se um intenso movimento de reforma na organização dos serviços de saúde, onde predomina a perspectiva de uma assistência a saúde baseada nas reais necessidades da populaçăo. Embora houve alguns marcos significativos de medidas direcionadas a solucionar as crises financeiras do sistemas de saúde, como a criaçăo do Conselho de Administraçăo de Saúde Previdenciária (CONASP) em 1982 e a Programa de Açőes Integradas (AIS), o impulso renovador se deu na VIII Conferência Nacional de Saúde em 1986, onde o projeto da Reforma Sanitáris brasileira foi expresso. ${ }^{25}$

Uma nova perspectiva da assistência à saúde toma conta no setor, e se dá continuidade às propostas da Reforma Sanitária de saúde como direito de todos, saúde como resultante das condições do meio e das formas de organização social da produçăo, e reformulação dos sistema nacional de saúde que tinha como princípios essenciais a universalidade, a integralidade, a descentralizaçăo e a participação popular. Em 1987, inicia-se o processo executivo de implantação através do Sistema Unificado e Descentralizado de Saúde (SUDS), que incorporou conteúdos estratégicos para o SUS, e da eleboração da nova Constituição Brasileira que ressalta alguns aspectos fundamentais da questão saúde: o conceito de saúde, entendido numa perspectiva de uma articulação de políticas sociais e económicas; o entendimento da saúde como direito universal derivado do exercício de uma cidadania plena; a caracterização das ações e serviços de saúde como de relevância pública; e a criação de um sistema de saúde organizado sob diretrizes de integridade, descentralização e participação da comunidade. Posteriormente essas diretrizes foram incorporadas em lei e promovidas a nivel local através das leis municipais de saúde e o movimento para a municipalização.

Quanto a prática de enfermagem nesse contexto, vários estudos da época apontam a problemática existente no setor saúde devido aos diversos sistemas de atenção à saúde existentes*. Em resposta aos acontecimentos na área sócio-política e de saúde no país, que visam a democratização e a equidade social, sur-

\footnotetext{
* Os Anais do $37^{\circ} \mathrm{CBEn}$ contém uma série de trabalhos que foram apresentados sobre a temática da situação da assistência de enfermagem nas diversas áreas de atuação e que delineam a problemática da enfermagem nos diversos setores.
} 
ge na enfermagem, a necessidade de buscar novos conceitos e abordagens dentro de uma prática mais social, ou seja, uma prática mais consciente de seu papel na determinaçăo dos rumos do setor saúde. Assim, em 1987, no $39^{\circ}$ CBEn realizado em Salvador, Bahia, inicia-se a análise crítica dos rumos da enfermagem e a procura de uma "redefiniçăo da prática"dentro do modelo de assistência à saúde proposta pelo movimento da Reforma Sanitária. ${ }^{23}$

O contexto sócio-político a partir de 1982, marcado com transformaçס̃es, e os acontecimentos na enfermagem brasileira, repercutiram no ensino de enfermagem de saúde pública na medida que se tenta compreendé-las. Uma característica do segundo período no ensino de saúde pública no Curso foi o surgimento do papel político do enfermeiro no que diz respeito ao desenvolvimento de seu processo de trabalho conhecendo a política de saúde vigente, pois os conteúdos refletiram uma certa mudança de enfoque, da assistência primária à análise das políticas de saúde.

Embora considere-se que esses conteúdos sejam necessários para uma análise crítica do contexto saúde e do trabalho e para o desenvolvimento das reformulações da prática, ele é insuficiente, pois os aspectos sócio-económicos gerais, tais como pobreza, moradia, desemprego, etc., em sua relação com saúde, foram enfoque de ensino de poucos programas. Contudo, entende-se que o Curso de Enfermagem da UFRN tenta mostrar, através desses conteúdos nas disciplinas de Enfermagem em saúde Pública, um primeiro passo para a reflexão de uma redefinição da prática.

\subsection{Concepções dos Enfermeiros Egressos sobre o Papel do Enfermeiro de Saúde Pública adquiridas no Curso e sua Cor- respondência na prática.}

Os enfermeiros egressos, na sua maioria, desenvolvem múltiplos processos de trabalho no emprego, mostrando como o trabalho de enfermagem nos serviços de saúde é diversificado. O enfermeiro se desdobra em funçőes administrativas, assistenciais, educativas e até de pesquisa, com a funcăo administrativa predominando.

A predominância das funçőes administrativas nos serviços de saúde, tem sido identificada em outros estudos. CASTELLANOS et al, ${ }^{10}$ ao analisar as temáticas dos Congressos Brasileiros de Enfermagem da década de 80, constatám que as açőes administrativas de enfermagem predominam no atendimento individual juntamente com as ações de cuidar. Sendo essa uma realidade concreta do processo de trabalho de enfermagem, essa prática multifuncional é um desafio quanto as suas possibilidades para a transformação qualitativa dos serviços.

As conceptualizaçőes do papel do enfermeiro em saúde pública que os egressos referiram terem adquirido no Curso, foram condizentes com aquelas conceptualizações projetadas nos conteúdos, ou seja, o papel assistencial e educativo do enfermeiro na área de prevenção, especialmente no periodo 1975-1981. Porém, expressando insatisfação e despreparo para enfrentar a prática quando recém graduados, a maioria dos enfeimeiros egressos nesse estudo, apontaram como principal deficiência do ensino em saúde pública, a falta de integração entre a teoria e a prática, ou seja, a desvinculação dos conteúdos com a realidade do serviço e o pouco conteúdo prático. Da mesma forma, os depoimentos emitidos pelos egressos quanto as dificuldades enfrentadas refletem uma carência de vivéncia prática no serviço de saúde. Referem situaçőes estressantes, onde não sabem nem por onde começar porque não sabem o que fazer,nem qual seja seu papel. Referem insegurança nas atividades assistenciais e administrativas. Referem péssimas condições de trabalho desconhecidas pela pouca vivência no serviço e que acabam dificultando o trabalho. É como se a realidade do serviço nunca tivera sido exposta para eles.

LUM ${ }^{19}$ explica que quanto maior a congruéncia das normas, valores, e expectativas entre as instituições de ensino da profissão e as realidades de trabalho, mais fácil se dará a transição de iniciante para profissional. KRAMER "Apud" LUM (19, p154) utiliza o termo "choque 
da realidade" para descrever o fenómeno das reações de choque do graduado quando se encontram em situaçőes de trabalho para o qual acha que está preparado e de repente se dá conta que não está. Esse choque ressalta a autora ocorre porque a socialização do estudante de enfermagem foi deficiente, deixando o graduado despreparado para funcionar efetivamente no mundo real. Segundo LUM, além de expor a realidade através de programas específicos de prática, o estudante deverá ser conscientizado de que seu aprendizado continua na vida profissional, pois a maior parte da profissionalização ocorre após a conclusão dos anos de ensino formal. Assim, a primeira experiéncia de trabalho deverá ser vista como uma continuação do processo de socialização à profissão, porque, segundo a autora, é ai onde os comportamentos específcos da sua profissão são internalizados.

Contudo, a questão de integração teoriaprática não é nova dentre os problemas do ensino em enfermagem. Tal incompatibilidade tem sido de grande preocupação no Curso da UFRN nas discussões de reforma curricular. Em 1988, o problema foi identificado com relação ao ensino de conceitos da assistência de enfermagem em geral. no Curso. 14 Com a exposição do problema de "choque da realidade" nos egressos, na área de enfermagem em saúde pública, torna urgente a procura de novos modelos de ensino que possam atender as necessidades do preparo de profissional para atuar nesse contexto, tendo em vista as exigéncias do SUS.

Alguns autores propõem açס̃es de integração docente-assistencial como soluções. ${ }^{15,16}$ Entre outras propostas encontra-se a idéia de inovação do ensino dos profissionais da saúde, onde o serviço de saúde serve de campo de um ensino integrado entre os Cursos da área de saúde. Como exemplo de tal programa pode-se citar o Projeto UNI ora em fase de implantação em diversas partes do Brasil. Já KRAMER apud LUM $^{19}$ sugere um programa de socialização, tipo estágio ou residência, como meio para transmitir os comportamentos específicos que atendem as exigências do serviço e orientar os en- fermeiros estudantes sobre a realidade sem perder de vista o que deveria ser.

Outras deficiências apontadas pelos egressos, tais como ensino de má qualidade, carga horária insuficiente e falta de estrutura, reiteram a necessidade de uma revisão pedagógica no Curso e no ensino de matéria relacionada à saúde pública em particular. Uma revisão quanto à qualificação dos professores, reformulação das disciplinas, aumento da carga horária prática, como também da avaliação periódica e qualitativa do ensino sendo realizado, é essencial.

\section{CONCLUSÃO}

Ao avaliar o ensino do papel do enfermeiro em saúde pública projetado no Curso de Enfermagem da UFRN no período de 1974-1990, pode-se afirmar que o mesmo tem uma relevância limitada na prática dos enfermeiros egressos. Embora corraborando a política de saúde vigente, o ensino não atinge seu potencial máximo devido às deficiéncias da estrutura curricular que limita carga horária teórico-prática e dicotomiza os conteúdos assistenciais, administrativos, educativos, e outros, falha esta que poderá ser atendida no currículo integrado ora em planejamento no Curso, que inclusive prevê um periodo de estágio profissional.

Os resultados da análise conduzem às seguintes conclusões específicas correspondentes às questões de pesquisa investigadas:

\section{Questão 1: Qual o papel do enfermeiro de saúde pública projetado no ensino?}

O papel do enfermeiro em saúde pública projetado nos conteúdos do Curso de Graduação em Enfermagem/UFRN de 1974 a 1990 focaliza funçőes múltiplas, assistenciais, educativas e administrativas dentro de uma perspectiva preventiva. $O$ objetivo da enfermagem em saúde pública focalizado nos programas na fase incial do Curso valorizou uma prática de assistência primária e, mais recentemente, a prevenção dentro de uma perspectiva de asistência coletiva, e de mudança e transformação nas políticas de saúde. Focaliza também o enfermeiro 
planejador, competente nas técnicas epidemiológicas, em detrimento das técnicas administrativas, dos aspéctos éticos e das atitude profissionais do enfermeiro.

\section{Questão 2: Qual a percepção do papel do enfermeiro em saúde pública adquirida pe- los graduados?}

O papel do enfermeiro em saúde pública adquirido pelos enfermeiros egressos, é de educador e conscientizador que objetiva a prevençăo da doença no atendimento individual. Essa percepção é reflexo do programa de estudo realizado que focalizou essa conceituação.

\section{Questão 3: Até que ponto o papel do enfer- meiro em saúde pública projetado no ensi- no se compatibiliza com as expectativas dos enfermeiros na prática?}

Embora compatível com o ensino, o papel năo atende as expectativas do enfermeiro na prática quando da inserçăo no mercado de trabalho, pois enfrenta sérias deficiências, precisando de treinamento especial para iniciar seu trabalho. No emprego, o enfermeiro é polivalente, enquanto o ensino valoriza a assistencia nos serviços de saúde. A divergéncia entre o ensino e a prática é o foco da insatisfaçăo dos enfermeiros egressos, apresentando insegurança técnica e despreparo para efetuar as atividades de assisténcia e de administraçăo exigidas nas unidades de saúde resultante da pouca vivência prática como estudante. Assim o enfermeiro egresso, experencia o "choque da realidade" caracterizado por frustração no seu trabalho e insatisfaçăo com a formação recebida.

A socializaçăo do enfermeiro para a vida profissional é de suma importância no ensino de graduação e portanto deverá ser compatível com as demandas do serviço. Os valores, atitudes e ações que o aluno integraliza no Curso centraram-se na prevenção da doença, embora em anos mais recentes haja uma tendéncia para promoçăo da saúde.
Questão 4: Até que ponto os conceitos e enfermagem em saúde pública utilizados no ensino se relacionam com a situação contextual, socio-econômica, política e de trabalho, nos serviços de saúde?

Os conceitos relacionados ao papel de enfermagem em saúde pública utilizados no ensino de enfermagem em saúde pública no período 1974 a 1990 no Curso de Enfermagem da UFRN, compatibilizaram-se com a situação política de saúde do país, que refletia uma política assistencial e individualizada na década de 1970 e que tornou-se gradativamente para a saúde coletiva numa perspectiva de reforma dos serviços na década de 1980. Contudo, essas conceptualizaçōes năo se adequam às exigéncias do serviço. Enquanto o Curso prepara enfermeiros assistenciais nos programas de saúde vigentes e educadores na área de prevenção e na assistência primária, a realidade do trabalho exige um profissional capacitado tecnicamente para exercer funçőes complexas de administraçăo de serviço e de coordenação da assistência de forma geral. Dentro da perspectiva do SUS, a ótica preventivista da saúde pública é superada pela ótica da vigilância à saúde. A prática exige uma visão de atenção integral à saúde e não da simples prevenção da doença. Existe, portanto, uma certa deficiéncia do papel do enfermeiro em saúde pública projetada no Curso para com as exigências dos serviços de saúde.

O envolvimento do ensino de enfermagem em saúde pública com os aspectos sócio-económicos do país e suas relações com a saúde não é claro, chegando a ser superficial, pois embora apresentem-se conteúdos sobre esses temas, a ligação entre esses condicionantes e a situação saúde não é explicita.

Ao considerar as conclusões do estudo algumas limitações terão que ser mencionadas. Os conteúdos programáticos das disciplinas que serviram de fonte de dados, na maioria das vezes não contém suficiente detalhamento para permitir uma análise mais completa. A amostra pequena de enfermeiros egressos foi outra limitação. Sugere-se que outros estudos simila- 
res utilizem também a tecnica de entrevista dos professores que lecionam a disciplina como terceira fonte de dados.

Perante às conclusões, é urgente a revisão dos modelos de ensino no currículo de enfermagem e em especial na matéria de enfermagem em saúde pública. Sugere-se que se empreenda uma reformulação dos conceitos por ocasião da reforma curricular, para que se assegure uma adequação entre a teoria e a prática no Curso de Graduação em Enfermagem da UFRN. Essa reflexão de conceitos novos na enfermagem em saúde pública deverá estar in- serida na realidade concreta do trabalho. Assim, os conceitos teóricos a serem estudados deverão partir da prática multi-funcional sendo realizada. Sugere-se, portanto, que estudos básicos sejam empreendidos, que permitam a eleboração de uma abordagem teórica de trabaIho assistencial da enfermagem dentro da perspectiva de atenção à saúde utilizando tais condicionantes como referencial. Isto possibilitará não só entender melhor o processo de trabalho de enfermagem do ponto de vista teórico, mas também, trará propostas mais objetivas para essa transformação que tanto se anseia.

ABSTRACT: The role of the public health nurse has been analysed in the teaching context, as a landmark for a practical evaluation. The aims are: 1) to identify the role of the public health nurse projected upon the programme contexts of the Rio Grande do Norte Federal University Nursing School public health subjects since its planting in 1974 up to 1990 and, 2) to evaluate the projected conceptions in teaching as to the reality of the graduated practices. The role theory conceptualizations led to the understanding of the term "role" and the concept internalization process.

Qualitative approach with data collection triangulation has been used. The data have been obtained from two sources: at course programme context and from graduated nurses from these courses. Document analysis technique has been applied for $70 \mathrm{Pu}-$ blic Health Subjects programmes and a stratified randomized sample of 60 nurses has been interviewed using a specific questionnaire. The data have been analysed under the light of the theory of papers for concept identifycation of concept. Next, the concept of health policy estabilished by the time of the study, has been analysed. The results have shown that the public health nurse projected into the contents focuses assistence , educative and administrative functions into a preventive view. The aim of public health nursing has been prevention, inside a primary assistance practice, and , more recently, inside a change and transformation perspective for the social questions and health policy. It focuses the planner nurse, competent at epidemiologycal tech-niques. The Graduated perception is also preventive and focuses an educative and aware role of the nurse, although little advance has been observed regarding to population social questions. There is an incompatibility between the concepts expressed at the course and the ones requested at the professional practice, reflecting graduated unsatisfaction with the formation acquired during the course that outstands technical insecurity at the practice. It has been concluded that the public health nursing practice has attended the demands of the up-to-date health policies, but not the nurse practice demands. Such a contrast between teaching and public health nursing shows the necessity of a curriculum revision as to the public health nursing work object.

KEYWORDS: Public Health Practice and Nursing Education - Public Health praxis 


\section{REFERÊNCIAS BIBLIOGRÁFICAS}

01 - ADAMI, N.P. Aspectos teóricos dos cuidados primários de saúde. R. Bras. Enferm. Brasilia, v.34, n. 1, p.8-14,1981.

02 - ALMEIDA, M.C.P.; MELLO, D.F.; NEVES, L.A.S. $O$ trabalho de enfermagem e sua articulação com o processo de trabalho em saúde coletiva na rede básica de saúde em Ribeirão Preto. R. Bras. Enferm. Brasilia, v.44, n.2/3, p.64-75, abril/set. 1991.

03 - ANDRADE, O.B.; ADAMI, N.P. Configuração das funções da enfermeira de saúde pública: modelo programático de preparo requerido para o exercicio dessas funçőes. $\mathbf{R}$. Enferm. Novas Dimens., São Paulo, v.2, n.6, p.308-318, 1976.

04 - BARROS, S.P.F. Enfermagem seu objetivo de trabalho. In: 33oCBEn, Manaus, 1981. Anais...Brasília: Aben, 1981, p.153-159.

05 - _ Política educacional em Enfermagem. In: SEMINÁRIO, A PRATTICA DE ENFERMAGEM E O CURRICULO DE GRADUAÇÃo, 1985, Ribeirão Preto. Anais... EERPI USP:. Ribeirão Preto, 1985. 221p. p. 13-33.

06 - BORGES, M.V. Tema II. Enfermagem e os serviços básicos de saúde. In: $38^{\circ} \mathrm{CBEn}$, 1985, Recife, 1985. Anais... ABEn: Recife, 1986. 550p. p.49-60.

07 - BOTOMÉ, S.P. Alguns fundamentos para a proposição de currículo centrado no comportamento. In: SEMINÅRIO: A PRÄTRICA DE ENFERMAGEM E O CURRICULO DE GRADUAÇÃO, 1985, Ribeirão Preto. Anais...EERP, USP: Ribeirão Preto, 1985. 221p. p.13-33.

08 - BRASIL, M.S., OPAS. Padrões mínimos para a assistência de enfermagem à comunidade. Brasília, 1977.

09 - BUENO, S.M.V.; VIETTA, E.P.; FREITAS, D.M.V. Inserção do enfermeiro na profissão: uma abordagem relacional de sua formação com a vivência profissional. R. Bras. Enferm. v. 40, n. 2/3, p.157-166, abr-set, 1987.
10 - CASTELLANOS, B.F. et al. Os desafios da enfermagem para os anos 90. 410. CBEn, Florianópolis, $2 / 7$ set., 1989. Anais...ABEn: Florianópolis, 1989. p.147-169.

11 - CHAVES, D.E. Papel da enfermagem dentro dos sistemas de saúde. R. Enferm. Atual, Rio de Janeiro, v.1, n.3, p. 4-8, jan/fev. 1979.

12 - CHRISTÓFARO, M.A.C. Currículo minimo para a formação do enfermeiro: na ordem do dia. Rev. Bras. Enferm., Brasilia, v. 44, n. 2/3, p. 7-9, abril/set, 1991.

13 - DOMINGUES, E.F. A enfermagem e os novos rumos da saúde comunitária. R. Paul Enferm., São Paulo, v.2, n. 2, p. 62-64, nov/ dez, 1982.

14 - ENDERS, B.C., et al. O ensino teórico-prático da assistência de enfermagem numa instituição de ensino: estudo de reflexão. Rev. Bras. Enferm., Brasilia, v.42, n. 1-4, p.22-26,89

15 - EGRY, E.Y.; BERTOLOZZI, M.R.; SHIMA, H. Integração docente-assiswtencial: a transformação do ensino e da assistência em saúde coletiva através da condução praxológica. Rev Esc. Enferm. USP, v. 25, n.2, p.169-176, ago., 1991.

16 - EGRY, E.Y.; FONSECA, R.M.G.S.; SHIMA, H.; SALUM, M.J.L. Processo de integração docente assistencial: espaço e movimento possiveis na construção do saber em saúde coletiva, Rev. Bras. Enferm., v.45, n.1, p.9-14, jan/mar.1992.

17 - HINSHAW, A.S. Role attitudes: a measurement problem. In: HARDY, M.E., CONWAY, M.E. Role Theory:perspectives for health professionals. New York: Appleton, Century Crofts, 1978.p. 273-304.

18 - KRIPPENDORFF, K. Content analysis: an introduction to its methodology. Newbury Park, Calif.: SAGE, 1980.

19 - LUM,J.J. Reference groups and professional socialization. In; HARDY, M.E., CONWAY, M.E. Role Theory: perspectives for health 
professionals. New York: Appleton, Century Crofts, 1978. p.137-156,

20 - MARTINS, A.A. A enfermagem como prática social. R. Bras. Enferm., Brasilia, v.40, n.2/ 3, p.132-143, abr-set, 1987.

21 - NOGUEIRA, M.J.C. Subsídios para descriçăo do conteúdo global da ocupação Enfermeira de Saúde Pública. Enf. Novas. Dimens., São Paulo, v.1, n.3, p.119-125, 1975.

22 - PASSOS, C.A. Saúde e trabalho: a crise da previdência social. Rio de Janeiro: Graal, 1981.

23 - ABEn Relatório final. In.: $42^{\circ}$ CBEn, ANAIS, Natal, 1990. 144p. p.124-126.

24 - SOUZA, A.M.A, et al. Seminário sobre "Prática da assistência": Redefinir ou reorientar a prática de enfermagem. In: $420 \mathrm{CBEn}, \mathrm{Na}-$ tal, 1990. Anais...Natal: ABEn -RN, 1992. p. $80-83$.

25 - TEIXEIRA, S.M.F. Evolução e crise de uma política social. R. Saúde ẹm Debate, Londrina, n.9, 1980.

\section{EQUIPE TÉCNICA:}

BERTHA CRUZ ENDERS, PhD em Enfermagem, Professora Adjunto, Departamento de Enfermagem/UFRN.

ROSANA LÚCIA ALVES DE VILAR, Enfa. Especialista, . Professora Adjunto, Departamento de Enfermagem/UFRN.

SÅNŻIA LÚCIA PAULINO DE SOUZA, Enfa. Especialista, Professora Adjunta, Departamento de Enfermagem/UFRN.

EFIGÉNIA MIGUEL DA SILVA, Enfa. Especialista, Professora Adjunta, Departamento de Enfermagem/UFRN.

MARIA DAS GRAÇAS PAIVA NICOLETE, Enfa. Mestre em Educaçăo, Professora Adjunto, Departamento de Enfermagem/UFRN.

MARIA DA SALETE BEZERRA DA COSTA, Mestre em Enfermagem, Professora Adjunto, Departamento de Enfermagem/UFRN.

ELIZABETH FERREIRA PIRES PAULO, Mestre em Enfermagem, Professora Adjunto, Departamento de Enfermagem/UFRN.

SHEILA ST. CLAIRE SILVA TEODÓSIO, Enfa. Mestre em Educaçăo, Professora Adjunto, Departamento de Enfermagem/UFRN.

FABIO DA CUNHA BORGES, Estudante de Enfermagem, Bolsista CNPq. 